\title{
SELECTION OF SUPERIOR GENOTYPES OF LIMA BEAN LANDRACES BY MULTIVARIATE APPROACH ${ }^{1}$
}

\author{
JOSÉ RIBAMAR DE ASSUNÇÃO FILHO ${ }^{2}$, MARCONES FERREIRA COSTA ${ }^{3 *}$, JOSÉ BALDIN PINHEIRO ${ }^{4}$, \\ LEONARDO CASTELO BRANCO CARVALHO ${ }^{2}$, REGINA LUCIA FERREIRA-GOMES ${ }^{2}$, \\ ÂNGELA CELIS DE ALMEIDA LOPES ${ }^{2}$
}

\begin{abstract}
The knowledge of genetic diversity in plant population is essential to the success of plant breeding programs. Thus, previous characterization of landraces is one of the first steps before the indication of genotypes to these plant breeding programs. This study aimed to characterize, through morphological traits, and estimate the genetic diversity in landraces of lima bean (Phaseolus lunatus L.). Genetic diversity was estimated by using multivariate methods that selected individual landraces to be indicated for farmers and consumers. According to morphological traits proposed by Biodiversity International, the genotypes UFPI-667 and UFPI682 showed higher dissimilarity and high potential to be used in crosses since they are genetically distant and complementary. The principal component analysis identified positive and significant phenotypic associations between variables: pod length, pod width, and grain production. According to the multivariate methods used, the landraces UFPI-666, UFPI-650, UFPI-651, UFPI-687, UFPI-658, UFPI-673, UFPI-667, and UFPI-674 are potential candidates for selection since they have relevant features for lima bean breeding, such as shorter cycles and higher grain production. This study showed that multivariate analysis can be used as an effective tool to find potential traits in lima bean and can assist the lima bean breeders in the selection of potential landraces. Accessions UFPI-667 and UFPI-682 can be indicated as genitors for breeding programs, as they are genetically distant and complementary in their characteristics.
\end{abstract}

Keywords: Breeding programs. Genetic diversity. Genetic resources.

\section{SELEÇÃO DE GENÓTIPOS SUPERIORES DE VARIEDADES CRIOULAS DE FEIJÃO-FAVA POR ABORDAGEM MULTIVARIADA}

RESUMO - O desenvolvimento de programas de melhoramento genético requer o conhecimento dos níveis de diversidade presente nas populações, desse modo o objetivo desse estudo foi caracterizar com base em descritores morfológicos a diversidade genética de variedades crioulas de feijão-fava (Phaseolus lunatus L.). A diversidade genética foi estimada a partir dos métodos multivariados que selecionaram variedades crioulas atendendo tanto os agricultores como o mercado consumidor. De acordo com as características morfológicas propostas pelo Biodiversity International, os genótipos UFPI-667 e UFPI-682 são os mais divergentes e apresentam alto potencial para serem utilizados em cruzamentos por serem geneticamente distantes e complementares. A análise de componentes principais detectou associações fenotípicas positivas e significativas entre as variáveis: comprimento da vagem, largura da vagem e produção de grãos. Ao usar métodos multivariados, as variedades crioulas UFPI-666, UFPI-650, UFPI-651, UFPI-687, UFPI-658, UFPI673, UFPI-667 e UFPI-674 são candidatos à seleção por apresentarem ciclos mais curtos e maiores produções de grãos, características importantes para o melhoramento do feijão-fava. Este estudo mostrou que as análises multivariadas podem ser usadas como uma ferramenta eficaz para encontrar características potenciais em feijão -fava e pode auxiliar os melhoristas de feijão-fava na seleção de variedades locais superiores. Os acessos UFPI667 e UFPI-682 podem ser indicados como genitores em programas de melhoramento genético, pois são distantes geneticamente e complementares em suas características.

Palavras-chave: Programas de melhoramento. Diversidade genética. Recursos genéticos.

\footnotetext{
${ }^{*}$ Corresponding author

${ }^{1}$ Received for publication in $09 / 02 / 2020$; accepted in 09/01/2021.

Paper extracted from the master's thesis of the first author.

${ }^{2}$ Department of Plant Science, Universidade Federal do Piauí, Teresina, PI, Brazil; ribamarfh@hotmail.com - ORCID: 0000-0002-70372091, cbcleonardo@gmail.com - ORCID: 0000-0001-5722-9322, rlfgomes@ufpi.edu.br - ORCID: 0000-0002-7700-6959, acalopes@ufpi.edu.br - ORCID: 0000-0002-9546-5403.

${ }^{3}$ Universidade Federal do Piauí, Floriano, PI, Brazil; marconescosta@ufpi.edu.br - ORCID: 0000-0001-8210-2673.

${ }^{4}$ Department of Genetics, College of Agriculture 'Luiz de Queiroz', Universidade de São Paulo, Piracicaba, SP, Brazil; jbladin@usp.br ORCID: 0000-0003-1294-2081.
} 


\section{INTRODUCTION}

Phaseolus lunatus L. (Fabaceae), commonly known as "lima bean", is the second most economically important species of the genus Phaseolus (MARTÍNEZ-NIETO et al., 2020). In Brazil, landraces are the main type of lima bean used by farmers and, usually, these landraces have high adaptation and rusticity. These features are important to be used in a plant breeding program since they provide a large source of genetic variability (PATERNIANI; NASS; SANTOS, 2000; SOUSA et al., 2020; SILVA et al., 2019a). Interestingly, lima bean landraces can grow under different environmental conditions and show a large variation in seeds traits, such as different sizes, shapes and colors (SILVA et al., 2015; SÁNCHEZ-NAVARRO et al., 2019).

Also, these landraces can have insensitivity to photoperiod and indeterminate growth and produce grains for several months, which contributes to food security. Among the most cropped type of lima bean, the landrace known as 'Boca de Moça' is preferred by small farmers and consumers (LOPES; ARAÚJO; GOMES, 2015) since it produces large seeds with white color and light brown seed coat pattern (BIOVERSITY INTERNATIONAL, 2007).

Although it is mostly cropped and preferred by farmers and consumers, particularly in the MidNorth region of Brazil, there is little information about the genetic diversity of this landrace, which limits its potential use in future plant breeding programs (CARMO et al., 2013; BARREIRO-NETO et al., 2015; PENHA et al., 2017). Thus, studies on the genetic diversity and traits of lima bean landraces belonging to 'Boca de Moça' group could contribute to the selection of potential lima bean varieties. According to Stoilova and Pereira (2013) and Penha et al. (2017), the knowledge of the genetic diversity is one of the most important steps in successful plant breeding programs.

Among the most used methods to characterize the plant genetic diversity, the multivariate approaches consist in a simultaneous evaluation of a wide range of traits that can make it possible to visualize different characteristics of a data set. These techniques have generated relevant information for studies on plant genetic resources, breeding and conservation since these methods allow, simultaneously, the measurement of different traits (TAVARES et al., 2018).

Cluster analysis (Unweighted Pair-Group Method Using Arithmetic Mean - UPGMA) and dispersion (principal components analysis - PCA) methods are examples of multivariate techniques used in the analysis of morphological data. UPGMA cluster analysis determined by Sneath and Sokal (1973) seeks to genetically discriminate individuals and allows them to be separated into groups by analyzing a set of characteristics inherent to each individual, so that there is homogeneity within the group and heterogeneity between groups (ROSA et al., 2019). Studies using the UPGMA method were carried out to identify variability among accessions of lima beans (GUIMARÃES et al., 2007; BRITO et al., 2020).

The most used dispersion method is principal component analysis, a technique that allows a simplification in the data set, summarizing it in a few variables with the ability to retain as much as possible of the variation that was originally available and still be independent of each other, which facilitates the identification of related genotype groups (HASSANPOUR; SAHHAFI, 2020).

Therefore, the use of multivariate methods in the selection of important plant traits can assist plant breeders in selecting the potential genotypes of lima bean to be used in breeding programs. Particularly for "Boca de Moça", as the most important lima bean landrace, the knowledge about potential morphological traits could contribute to further breeding program. Thus, this study characterized and estimated, by using multivariate approaches, the genetic diversity of "Boca de Moça" landraces found in Piauí state, Northeastern, Brazil.

\section{MATERIAL AND METHODS}

Seeds of 48 landraces belonging to 'Boca de Moça' group were collected in Piauí state, Brazil (Figure 1). These areas were selected according to the production database from IBGE (IBGE, 2018) as the most important in 'Boca de Moça" production. These seeds were sown in the Experimental Field belonging to the Plant Science Department of the Federal University of Piauí (UFPI), Teresina, PI, Brazil $\left(05^{\circ} 05^{\prime} \mathrm{S}, 42^{\circ} 48^{\prime} \mathrm{W}, 72 \mathrm{~m}\right)$. The climate is Aw" according to Köppen's classification. Due to the significant number of accessions assessed and aiming to control environmental heterogeneity, the experimental design used was $7 \times 7$ lattice and the plants were spaced apart by $1.5 \mathrm{~m} \times 1.5 \mathrm{~m}$. The sowing consisted of three seeds per point and, after two weeks, the plants were thinned to leave only one.

For each landrace, morphological, phenological and agronomic traits were evaluated during the growing season (from January through September 2010). All traits were based on the Lima Bean Descriptors (BIOVERSITY INTERNATIONAL, 2007): number of days to flowering (NDF); number of days to maturity (NDM); number of pods per plant (NPP); pod length (PL); pod width (PW); pod thickness (PT); number of locules per pod (NLP); number of seeds per pod (NSP); 100-seed weight (100-SW); and grain production per plant (GP). The traits related to the pod and seeds were measured considering the average from ten randomly chosen ripe pods. 


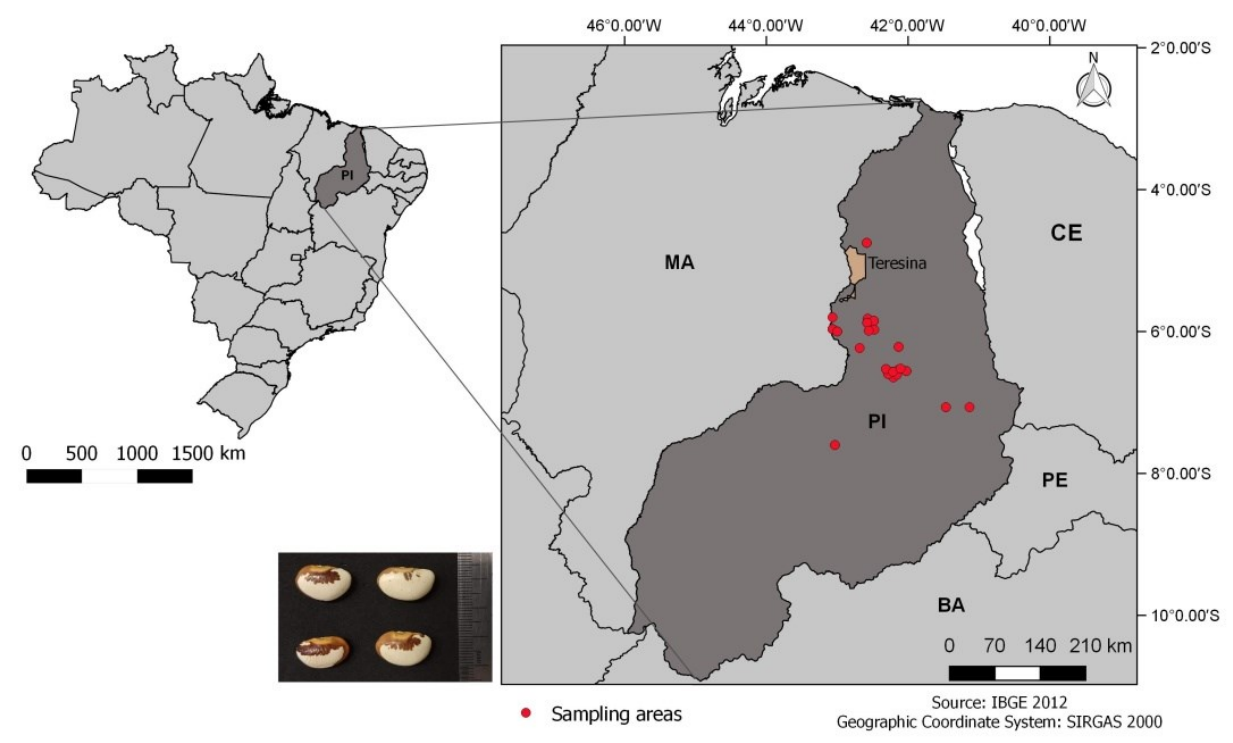

Figure 1. Geographical distribution of the lima bean accessions studied.

We used Spearman's correlations for the analysis of traits. Principal Component Analysis (PCA) was performed to inform which of the variables analyzed throughout the experiment contributed the most to the genetic diversity found. The estimation of Euclidean Genetic Distance matrices was conducted via the Unweighted PairGroup Method Using with Arithmetic Mean (UPGMA) and then the genetic diversity analyses were estimated.

Analyses of consistency between the phenetic and cophenetic matrix was made by cophenetic correlation. The discriminant analysis of principal components (DAPC) and the probability of association were performed using the a priori information of the phenotypic characteristics evaluated to verify the consistency of the groups formed. All statistical-genetic analyses were performed with the aid of the computer program $\mathrm{R}$ software ( $R$ DEVELOPMENT CORE TEAM, 2018)

\section{RESULTS AND DISCUSSION}

Positive and significant correlations (magnitude of $0.4<\mathrm{r}>0.7$ ) were found between NDF and NDM (Table 1), while NPP, PL, PW and PT were positively correlated with one another, and these traits are important to be considered during the selection of potential genotypes (Table 1). Other positive correlations were found between PL, PW, NSP, and NLP. The estimations of the correlation coefficient were positive and significant between GP and NPP (0.95), PL (0.74), 100-SW (0.62), PW
(0.52) and PT (0.37). These results mean that these landraces do not lose their ability to produce a large number of pods, even with higher pod length.

Maia et al. (2020) highlight the importance of correlation analysis for breeding, as these associations quantify the possibility of indirect gains by selection in correlated traits. Therefore, obtaining the correlation between traits of interest in lima bean can facilitate the selection of accessions and reduce the work of the breeder in indicating genotypes that meet the demands of farmers.

Principal component analysis (PCA) was used to determine the most significant descriptors in the data set. The total variation of $74.57 \%$ (Table 2), obtained from the first three principal components, has a significant part able to show variation of the genetic origin. Morrison (1976) warns that the first two components should retain $75 \%$ of all variation, while Cruz, Regazzi and Carneiro (2012) recommend that at least $80 \%$ of the variation be present in the first two principal components. However, some studies have indicated that, although this limit is not reached, the analysis could be effective in evaluating the genetic diversity (RODRIGUES et al., 2002; COELHO et al., 2007; BERTINI et al., 2010; SILVA et al., 2019a; MAIA et al., 2020; ZARGAR et al., 2021).

The eigenvectors associated with the first component (PC1) showed PL (0.43), PW (0.38) and GP (0.37) as the most important traits representing plant yield (Table 3). Thus, landraces that showed higher values in PC1 had the better values for the yield component. On the other hand, NDF and NDM were found in the second principal component (PC2) and they are linked to plant cycle. 
Table 1. Estimates of phenotypic correlation coefficients among the evaluated characters in 49 Lima bean accessions of "Boca de Moça" landrace varieties.

\begin{tabular}{|c|c|c|c|c|c|c|c|c|c|}
\hline & NDM & NPP & PL & PW & PT & NLP & NSP & $100-\mathrm{SW}$ & GP \\
\hline $\mathrm{NDF}$ & $0.58^{* *}$ & $0.08^{\mathrm{ns}}$ & $0.03^{\mathrm{ns}}$ & $0.07^{\mathrm{ns}}$ & $-0.06^{\mathrm{ns}}$ & $0.11^{\mathrm{ns}}$ & $-0.03^{\mathrm{ns}}$ & $0.03^{\mathrm{ns}}$ & $0.10^{\mathrm{ns}}$ \\
\hline NDM & & $-0.07^{\mathrm{ns}}$ & $-0.01^{\mathrm{ns}}$ & $-0.04^{\mathrm{ns}}$ & $-0.12^{\mathrm{ns}}$ & $0.04^{\mathrm{ns}}$ & $-0.04^{\mathrm{ns}}$ & $0.03^{\mathrm{ns}}$ & $-0.07^{\mathrm{ns}}$ \\
\hline NPP & & & $0.70 * *$ & $0.52 * *$ & $0.39 * *$ & $0.15^{\mathrm{ns}}$ & $0.21^{\mathrm{ns}}$ & $0.53 * *$ & $0.95^{* *}$ \\
\hline PL & & & & $0.68 * *$ & $0.49 * *$ & $0.47 * *$ & $0.37 * *$ & $0.39 * *$ & $0.74 * *$ \\
\hline PW & & & & & $0.29 *$ & $0.37 * *$ & $0.30 *$ & $0.15^{\mathrm{ns}}$ & $0.52 * *$ \\
\hline $\mathrm{PT}$ & & & & & & $0.25^{\mathrm{ns}}$ & $0.19^{\mathrm{ns}}$ & $0.19^{\mathrm{ns}}$ & $0.37 * *$ \\
\hline NLP & & & & & & & $0.78 * *$ & $-0.06^{\mathrm{ns}}$ & $0.15^{\mathrm{ns}}$ \\
\hline NSP & & & & & & & & $-0.01^{\mathrm{ns}}$ & $0.17^{\mathrm{ns}}$ \\
\hline $100-S W$ & & & & & & & & & $0.62 * *$ \\
\hline
\end{tabular}

NDF- number of days to flowering, NDM - number of days to maturity, NPP - number of pods per plant, PL - pod length, PW - pod width, PT - pod thickness, NLP -number of locules per pod, NSP - number of seeds per pod, 100-SW - 100-seed weight, GP - grain production. **, * and ${ }^{\text {ns }}$, significant at $1 \%$, at $5 \%$ and not significant, respectively.

Table 2. Variance (eigenvalues) of each principal component and its importance in relation to the total variance evaluated in 48 populations of lima bean.

\begin{tabular}{ccc}
\hline Component & Variance & Accumulated variance (\%) \\
\hline 1 & 4.35 & 43.48 \\
2 & 1.79 & 61.35 \\
3 & 1.32 & 74.57 \\
4 & 0.83 & 82.87 \\
5 & 0.63 & 89.17 \\
6 & 0.39 & 93.07 \\
7 & 0.31 & 96.17 \\
8 & 0.19 & 98.10 \\
9 & 013 & 99.43 \\
10 & 0.06 & 100.00 \\
\hline
\end{tabular}

Table 3. Eigenvectors associated with: number of days to flowering (NDF), number of days to maturity (NDM), number of pods per plant (NPP), pod length (PL), pod width (PW), pod thickness (PT), number of locules per pod (NLP), number of seeds per pod (NSP), 100-seed weight (100-SW), and grain production (GP), and each principal component evaluated in 49 Lima bean accessions of "Boca de Moça" landrace varieties.

\begin{tabular}{|c|c|c|c|c|c|c|c|c|c|c|}
\hline \multirow{2}{*}{ Character } & \multicolumn{10}{|c|}{ Components } \\
\hline & 1 & 2 & 3 & 4 & 5 & 6 & 7 & 8 & 9 & 10 \\
\hline NDF & 0.16 & 0.54 & 0.33 & 0.02 & -0.24 & 0.69 & 0.04 & 0.02 & -0.17 & 0.02 \\
\hline NDM & 0.13 & 0.54 & 0.39 & -0.01 & -0.18 & -0.65 & 0.04 & 0.18 & 0.22 & 0.03 \\
\hline NPP & 0.37 & -0.33 & 0.24 & -0.17 & -0.14 & 0.00 & 0.44 & 0.07 & -0.01 & -0.67 \\
\hline PL & 0.43 & 0.07 & -0.12 & 0.08 & -0.11 & -0.25 & -0.02 & -0.68 & -0.49 & 0.09 \\
\hline PW & 0.38 & -0.18 & -0.07 & -0.12 & -0.35 & 0.01 & -0.77 & 0.27 & 0.03 & -0.09 \\
\hline $\mathrm{PT}$ & 0.24 & -0.01 & -0.36 & 0.77 & -0.27 & 0.02 & 0.25 & 0.25 & 0.14 & 0.05 \\
\hline NLP & 0.37 & 0.25 & -0.27 & -0.12 & 0.34 & 0.16 & -0.06 & -0.31 & 0.67 & -0.13 \\
\hline NSP & 0.36 & 0.20 & -0.27 & -0.18 & 0.53 & -0.06 & 0.09 & 0.51 & -0.42 & 0.06 \\
\hline 100-SW & 0.14 & -0.18 & 0.57 & 0.51 & 0.52 & 0.02 & -0.27 & -0.05 & -0.02 & -0.05 \\
\hline GP & 0.37 & -0.36 & 0.24 & -0.22 & -0.07 & 0.08 & 0.26 & 0.05 & 0.19 & 0.71 \\
\hline
\end{tabular}

UFPI-666, UFPI-650, UFPI-651, UFPI-687, UFPI-658, UFPI-673 and UFPI-667 were classified as early landraces, while UFPI-684, UFPI-652 and UFPI-686 showed late cycle. Maturity time is an essential and desirable trait in crop improvement since early lima bean genotypes are less susceptible to pest and disease attack, lowering production costs; therefore, these early accessions could be promising.

The Euclidean distance was estimated to verify the divergence among the landraces. The greatest distance (186.62) was found between UFPI667 and UFPI-682, while UFPI-661 and UFPI-702 showed the lowest distance. The greater genetic 
distance between UFPI-667 and UFPI-682 can be explained by the fact that these accessions are contrasting with most characters; interestingly, the landrace UFPI-682 has a longer cycle compared to UFPI-667, although it showed higher values of NPP, PL, PW and PT.

The UPGMA was used to estimate the genetic diversity between landraces (Figure 2). This method is an effective statistical tool that gives a clear idea about the diverse nature of the population under evaluation. A wide range was observed for cluster means of all traits indicating a significant contribution of all the traits in clustering. Cluster 1 was represented by UFPI-674 and UFPI-667 as they showed the highest values of GP. However, the biggest cluster (cluster 2) consisted of UFPI-701, UFPI-656, UFPI-657, UFPI-705, UFPI-685, UFPI-
702, UFPI-661, UFPI-667, UFPI-655, UFPI-669, UFPI-697, UFPI-668, UFPI-679, UFPI-652, UFPI670, UFPI-678, UFPI-692, UFPI-694, UFPI-698, UFPI-682, UFPI-665, UFPI-664, UFPI-689, UFPI658, UFPI-686, UFPI-659, UFPI-662, UFPI-681, UFPI-684, UFPI-690, UFPI-675, UFPI-687, UFPI691, UFPI-693, UFPI-695, UFPI-663, and UFPI680. This cluster grouped landraces with lowest values of yield components and late cycle. The rest of the landraces were grouped in cluster 3 .

The cophenetic correlation value observed in the dendrogram $(\mathrm{ccc}=0.77)$ indicates the suitability of the grouping method. Recently, Rohlf (1970) reported that ccc lower than 0.7 is inappropriate and low values indicate that the clustering method was not efficient in representing a dissimilarity matrix or showed low correlation.

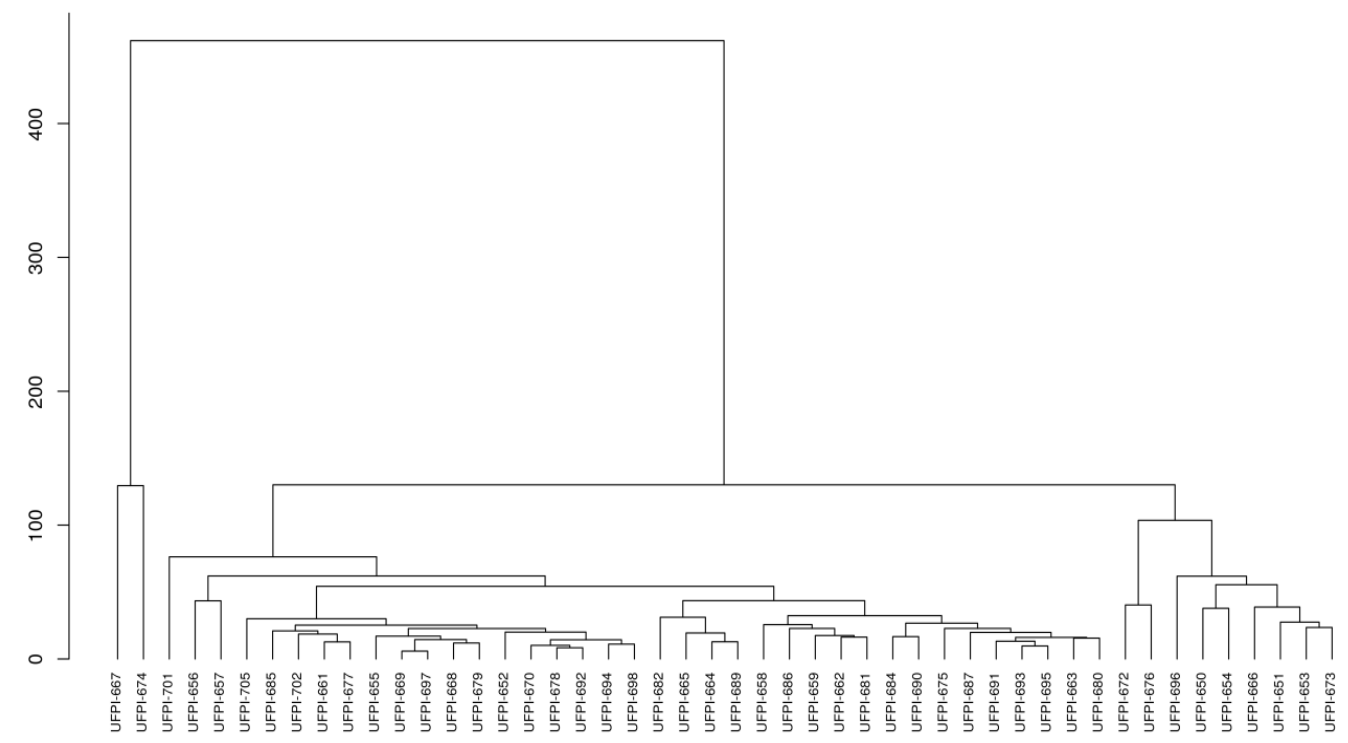

Figure 2. Dendrogram generated by the UPGMA method for the analyzed 'Boca de Moça' landrace varieties.

Based on the three clusters found from UPGMA method with Euclidean distances, the cross between individual landraces belonging to genetically divergent groups can be performed aiming to obtain heterogeneous and transgressive segregation in progenies that express high yield and early cycle. Therefore, the genetically different landraces of the three groups could be used in genetic breeding program.

Previous studies have revealed that the use of multivariate methods is important to estimate the diversity of lima bean germplasm (GONÇALVES et al., 2019; BRITO et al., 2020). Brito et al. (2020) used morphoagronomic traits to characterize eleven genotypes of lima bean from Ceará state, Northeastern Brazil, and found five clusters by using UPGMA method. Earlier, Gonçalves et al. (2019) evaluated eight lima bean genotypes and found three divergent groups.
Grouping methods are important for the selection of genetically distant genotypes and these characteristics can be recommended for hybridization, which is essential for autogamous breeding programs (CRUZ; REGAZZI; CARNEIRO, 2012). Thus, UFPI-667 and UFPI-682 landraces may be used in breeding because they are genetically distant and complementary in their characteristics. Silva et al. (2015) characterized accessions of lima bean, by morphoagronomic traits, and indicated the cross between UFPI-220 and UFPI -468 for breeding programs, since they showed high levels of dissimilarity and average performance, with important characteristics for the production components.

According to Deepika et al. (2021), while UPGMA, a powerful tool, quantifies the genetic divergence in germplasm, principal component analysis (PCA) helps in the identification of a set of genotypes capturing maximum genetic diversity of 
the collection, and both are efficient in separating the accessions into genetically divergent clusters. Besides, PCA detected positive and significant phenotypic association between the variables: pod length, pod width and grain production. For grain production, we can indirectly select accessions based on these characters, since these variables show higher heritability when compared to grain production. Thus, the application of these multivariate tests is critical for these studies (CRUZ; REGAZZI; CARNEIRO, 2012).

The discriminant analysis (DAPC) separated landraces according to their primary differences in production and cycle (Figure 3 ). An overlap between groups 1 and 2 was found, showing a degree of proximity. Group 1 clustered the most productive landraces, while group 2 clustered those with early cycle. Interestingly, group 3 clustered only UFPI701, which had the lowest yield.

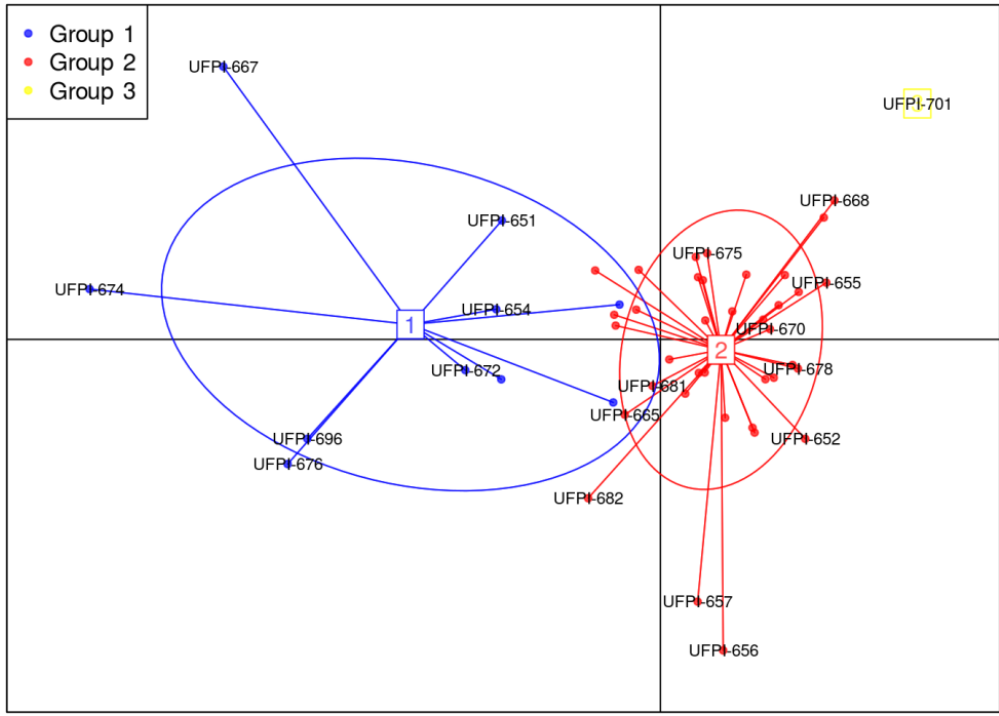

Figure 3. Scatter plot of the 48 "Boca de Moça" landrace varieties in the discriminant analysis of principal components (DAPC). Each color symbolizes groups obtained a priori and therefore provides the possibility to check consistency of this group with respect to the DAPC.

The results have shown a slight consistency comparing the dendrogram (Figure 2) and the groups formed by discriminant analysis (Figure 3). Although both analyses combined landraces into three groups, there was a variation in number of landraces per group. However, group 1, in both methods, clustered the landraces UFPI-667 and UFPI-674, which had the highest values related to production. In addition, the result of DAPC (Figure 3 ) showed the dispersion of landraces with a small overlap between groups 1 and 2, and there was a clear separation as the landraces are more (group 1) or less (group 3) productive.

The landraces UFPI-651, UFPI-654, UFPI672 and UFPI-673 showed values of probability greater than $80 \%$ in group 2, while UFPI-668 and UFPI-679 had less than $20 \%$ of probability within group 3 (Figure 4). The majority of the landraces showed about $80 \%$ of probability for group 1 .

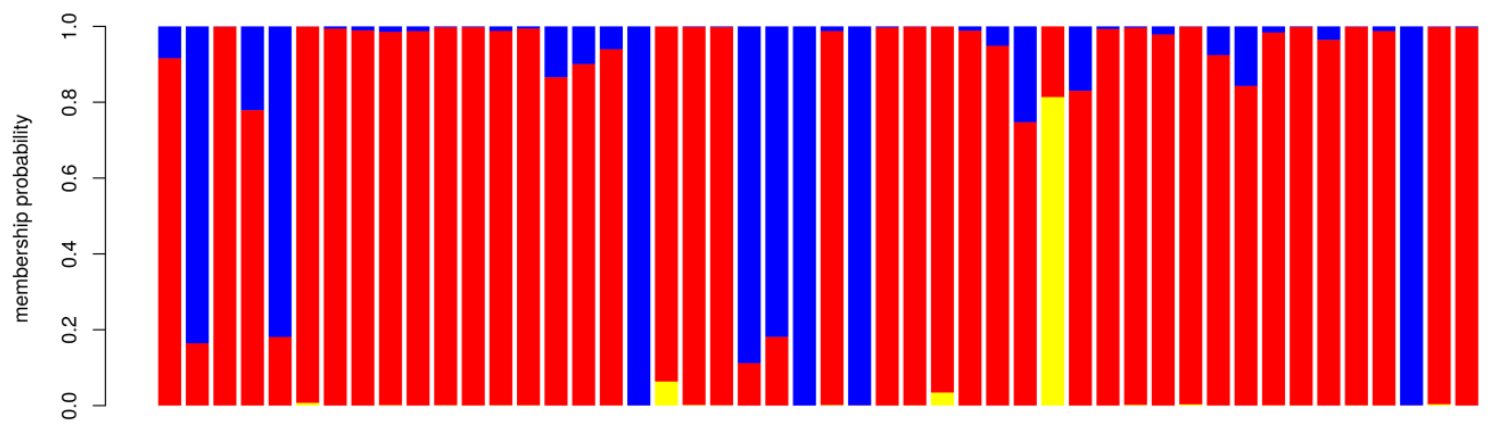

品

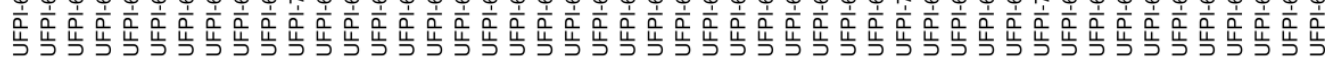

Figure 4. Probability of an accession belonging to the group that was associated with the DAPC, adopting the Gower's generalized distance. Colors represent the three groups. 
In this study, the genetic diversity of lima bean was assessed in 48 landraces belonging to 'Boca de Moça' group. Our findings are important to the studies on lima bean breeding since there is no variety or cultivar indicated to be used in Northeastern, Brazil, and the landraces belonging to 'Boca de Moça' are the most used by farmers. Indeed, the understanding of the agronomic potential of lima bean landraces could be important for their further use in plant breeding programs (BARREIRANETO et al., 2015; SILVA et al., 2017; GRIGOLO et al., 2018; JESUS et al., 2018; SILVA et al., 2019b).

Multivariate methods are useful for the selection of promising genotypes in breeding programs (CRUZ; REGAZZI; CARNEIRO, 2012). Indeed, our results showed that all multivariate methods, i.e. PCA, UPGMA and DAPC, were efficient in indicating the potential landraces. Since we found high correlation between plant traits, these multivariate analyses allowed better choice of landraces (MAIA et al., 2019). By using these multivariate methods, the landraces UFPI-666, UFPI-650, UFPI-651, UFPI-687, UFPI-658, UFPI-673, UFPI-667 and UFPI-674 had higher values of traits related to yield. Since these landraces had early cycle, their potential in increasing plant yield is important to farmers who cultivate lima bean during short periods under rainfed conditions. Thus, there is a potential for using these landraces in lima bean breeding. Interestingly, UFPI-667 was the most productive landrace and also showed the shortest cycle, being potentially indicated in breeding programs.

Our results suggest that the genetic divergence found among the landraces is fundamental to indicate and select those that will compose the next selection cycle. Further, the selection cycle will produce segregant and improved population with desirable features for commercialization. Therefore, the genetic characterization is crucial for the development of the genetic breeding programs that will generate more productive and early genotypes, meeting the needs of farmers.

\section{CONCLUSION}

The landraces UFPI-667 and UFPI-682 are genetically distant and complementary, being potentially indicated to be used in crosses. The landraces UFPI-666, UFPI-650, UFPI-651, UFPI-687, UFPI-658, UFPI-673, UFPI-667 and UFPI-674 are also good candidates to selection because they have alleles related to important agromorphological traits for lima bean. The multivariate analyses (PCA, DAPC and UPGMA) were important to make decisions and visualize the relations among the potential landraces belonging to 'Boca de Moça' group, and they can assist the selection of landraces that could be interesting to consumers and farmers.

\section{ACKNOWLEDGMENTS}

To the Coordination for the Improvement of Higher Education Personnel (CAPES) for the award of scholarships and financial support for the project Academic Cooperation to Enhance Post-graduation Formation in Genetics and Breeding (PROCAD UFPI/ESALQ), No. 23038.042963/2008-14. To the Luiz de Queiroz College of Agriculture (ESALQ), especially the Genetics Department, for making laboratory facilities available. To the National Council for Scientific and Technological Development (CNPq) for funding.

\section{REFERENCES}

BARREIRO-NETO, $M$. et al. Características morfológicas e produtivas em acessos de feijão-fava consorciados. Revista Tecnologia \& Ciência Agropecuária, 9: 23-27, 2015.

BERTINI, C. H. C. M. et al. Análise multivariada e índice de seleção na identificação de genótipos superiores de feijão-caupi. Acta Scientiarum. Agronomy, 32: 613-619, 2010.

BIOVERSITY INTERNATIONAL. Guidelines for the development of crop descriptor lists. Bioversity Technical Bulletin Series, 12: 2-2, 2007.

BRITO, M. V. et al. Univariate and multivariate approaches in the characterization of lima bean genotypes. Revista Caatinga, 33: 571-578, 2020.

CARMO, M. D. S. D. et al. Genetic variability in subsamples of determinate growth lima bean. Crop Breeding and Applied Biotechnology, 13: 158-164, 2013.

COELHO, C. M. M. et al. Diversidade genética em acessos de feijão (Phaseolus vulgaris L.). Ciência Rural, 37: 1241-1247, 2007.

CRUZ, C. D.; REGAZZI, A. J.; CARNEIRO, P. C. $\mathrm{S}$. Modelos biométricos aplicáveis ao melhoramento genético. 4 ed. Viçosa, MG: UFV, 2012, 514 p.

DEEPIKA, $K$. et al. Multivariate analysis of geographically diverse rice germplasm for genetic improvement of yield, dormancy and shatteringrelated traits. Plant Genetic Resources, 19: 144152,2021 
GONÇALVES, G. M. C. et al. Genetic dissimilarities between fava bean accessions using morphoagronomic characters. Revista Caatinga, 32: 1125-1132, 2019.

GRIGOLO, S. et al. Implicações da análise univariada e multivariada na dissimilaridade de acessos de feijão comum. Revista de Ciências Agroveterinárias, 17: 351-360, 2018.

GUIMARÃES, W. N. R. et al. Caracterização morfológica e molecular de acessos de feijão-fava (Phaseolus lunatus L.). Revista Brasileira de Engenharia Agrícola e Ambiental, 11:37-45, 2007.

HASSANPOUR, F.; SAHHAFI, S. R. Genetic variation in some Iranian bitter vetch (Vicia ervilia L.) landraces based on agronomic-morphological traits for use in breeding program in Rafsanjan. Genetic Resources and Crop Evolution, 67: 20872100, 2020.

IBGE - Instituto Brasileiro de Geografia e Estatística. Banco de dados agregados: pesquisa: produção agrícola. Piauí, 2018. Disponível em: $<$ http://www.ibge.gov.br>. Acesso em: 23 nov. 2018.

JESUS, L. D. G. A. et al. Eficiência de testes colorimétricos para determinação da viabilidade do pólen em acessos de feijão-fava (Phaseolus lunatus L). Revista Brasileira de Agropecuária Sustentável, 8: 1-8, 2018.

LOPES, A. C. A.; ARAÚJO, A. S. F.; GOMES, R. L. F. Phaseolus lunatus: diversity, growth and production. Nova Publishers, 2015. 175 p.

MAIA, M. C .C. et al. Principal component and biplot analysis in the agro-industrial characteristics of Anacardium spp. European Scientific Journal, 15:21-31, 2019 .

MAIA, M. C. C. et al. Early selection in a population of the mangaba (Hancornia speciosa Gomes). Revista Agro@mbiente On-line, 14: 1-13, 2020.

MARTÍNEZ-NIETO, M. S. et al. Resilience Capacity Assessment of the Traditional Lima Bean (Phaseolus lunatus L.) Landraces Facing Climate Change. Agronomy. 10: 758-773, 2020.

MORRISON, D. F. Multivariate statistical methods. 2. ed. Singapore: McGraw-Hill, 1976. 415 p.

PATERNIANI, E.; NASS, L. L.; SANTOS, M. X. O valor dos recursos genéticos de milho para o Brasil: uma abordagem histórica da utilização do germoplasma. In: UDRY, C. W.; DUARTE, W. (Org.) Uma história brasileira do milho: o valor dos recursos genéticos. Brasília, DF: Paralelo, 2000 v. 15, p. $11-41$

PENHA, J. S. et al. Estimation of natural outcrossing rate and genetic diversity in Lima bean (Phaseolus lunatus L. var. lunatus) from Brazil using SSR markers: implications for conservation and breeding. Genetic Resources and Crop Evolution, 64: 13551364, 2017.

R DEVELOPMENT CORE TEAM. R (2018): a language and environment for statistical computing. Vienna: R Foundation for Statistical Computing.

RODRIGUES, L. S. et al. Divergência genética entre cultivares locais e cultivares melhoradas de feijão. Pesquisa Agropecuária Brasileira, 37: 1285-1294, 2002.

ROSA, T. L. M. et al. Biometry and genetic diversity of paradise nut genotypes (Lecythidaceae). Pesquisa Agropecuária Brasileira, 54:1-9, 2019.

ROHLF, F. J. Esquemas de cluster hierárquico adaptáveis. Systematic Biology, 19: 58-82, 1970.

SÁNCHEZ-NAVARRO, V. et al. 2019. Comparing legumes for use in multiple cropping to enhance soil organic carbon, soil fertility, aggregates stability and vegetables yields under semi-arid conditions. Scientia Horticulturae, 246: 835-841, 2019.

SILVA, V. B. et al. Diversidade genética e indicação de cruzamentos promissores entre acessos de feijãofava (Phaseolus lunatus). Semina Ciencias Agrarias, 36: 683-692, 2015.

SILVA, R. N. O. et al. Phenotypic diversity in lima bean landraces cultivated in Brazil, using the WardMLM strategy. Chilean Journal of Agricultural Research, 77: 35-40, 2017.

SILVA, R. N. O. et al. High diversity of cultivated lima beans (Phaseolus lunatus) in Brazil consisting of one Andean and two Mesoamerican groups with strong introgression between the gene pools. Genetics Molecular Research, 18: 1-15, 2019a.

SILVA, S. I. A. et al. Uma Avaliação dos componentes de produção em variedades crioulas de fava cultivadas no Agreste da Paraíba. Revista de Ciências Agrárias, 42: 731-742, 2019b.

SOUSA, A. M. C. B. S. et al. 2020. Prediction of grain yield, adaptability, and stability in landrace varieties of lima bean (Phaseolus lunatus L.). Crop Breeding and Applied Biotechnology, 20: 1-7, 2020. 
SNEATH, P. H.; SOKAL, R. R. The principles and practice of numerical classification. Numerical taxonomy, 573: 39-42 1973 .

STOILOVA, T.; PEREIRA, G. Assessment of the genetic diversity in a germplasm collection of cowpea (Vigna unguiculata (L.) Walp.) using morphological traits. African Journal of Agricultural Research, 8: 208-215, 2013.

TAVARES, T. C. O. et al. Divergência genética entre cultivares de feijão comum cultivados no estado do Tocantins. Journal of Neotropical Agriculture, 5: 76-82, 2018.

ZARGAR, S. A. et al. Analysis of phenotypic diversity of apricot (Prunus armeniaca L.) accessions from Jammu and Kashmir, India. Plant Genetic Resources, 1: 1-13, 2021. 